\title{
Respon Pertumbuhan dan Produksi Beberapa Varietas Jamur Tiram Pada Kombinasi Media Serbuk Limbah Pelepah Kelapa Sawit dan Serbuk Gergaji
}

\section{Growth Respond and Production of Oyster Mushroom on The Combination of Palm Waste and Sawdust}

\author{
Meidaya Bate'e' 1 , Ellen Lumisar Panggabean'2), Siti Mardiana1)* \\ 1) Prodi Agroteknologi, Fakultas Pertanian, Universitas Medan Area, Indonesia
}

\begin{abstract}
Abstrak
Permintaan pasar akan jamur setiap tahunnya meningkat. Sehingga perlu peningkatan produksi daripada jamur tiram. Tujuan penelitian adalah untuk mengetahui respon pertumbuhan dan produksi beberapa varietas jamur tiram pada media serbuk limbah pelepah sawit dan gergaji. Penelitian dilaksanakan di Sumatera Kebun Budidaya Jamur Tiram. Rancangan yang digunakan dalam penelitian ini adalah Rancangan Acak Lengkap (RAL) faktorial yang tediri dari 2 faktor. Faktor pertama adalah komposisi media tanam serbuk pelepah sawit dan gergaji dan beberapa varietas jamur tiram dengan 2 ulangan. Parameter pengamatan pada penelitian yaitu persentase baglog yang ditutupi miselium (\%), pertumbuhan miselium pada substrat (cm), umur munculnya tubuh buah (HSI), jumlah tubuh buah (buah), diameter tudung buah (cm2) Panjang tangkai tubuh buah $(\mathrm{cm})$ dan bobot basah panen (g). Hasil penelitian menunjukkan bahwa perlakuan terbaik untuk pertumbuhan miselium dan umur munculnya tubuh buah pada media 100\% serbuk kelapa sawit dan varietas jamur tiram merah dengan kombinasi terbaik yaitu M1V2 yaitu 58,38 hari terbentuknya tubuh buah pertama.

Kata Kunci: Jamur tiram putih, jamur tiram merah, jamur tiram coklat, serbuk pelepah kelapa sawit, serbuk gergaji
\end{abstract}

\begin{abstract}
The demand of oyster mushroom has increased. Hence the production should be improved as well. The purpose of research is to know the growth response and production of several varieties of oyster mushroom on the powder media of palm stem waste and sawdust. Research conducted in Sumatra mushroom oyster cultivation. The design used in this study is a Complete Random Design (CRD) factorial that is of 2 factors. The first factor is the composition of the planting media of palm oil and sawdust was conducted with 2 repeats. The Parameter of observation on the study is the percentage of baglogs covered by mycelium (\%), the growth of mycelium on the substrate (cm), the age of the body of the fruit (DAI), Number of fruit body (fruit), diameter of the hood (cm2) The stem length of the fruit body (cm) and the wet Harvest weight $(\mathrm{g})$. The results showed that the best treatment for the growth of mycelium and the age of fruit body in total saw dust amd and varieties jamur tiram 58.38 days formation of the first fruit body.

Keywords: white oyster mushroom, red oyster mushroom, brown oyster mushroom, palm oil stem powder, sawdust
\end{abstract}

How to Cite: Meidaya Bate'e, Ellen Lumisar Panggabean \& Siti Mardiana (2020). Respon Pertumbuhan Dan Produksi Beberapa Varietas Jamur Tiram Pada Kombinasi Media Serbuk Limbah Pelepah Kelapa Sawit Dan Serbuk Gergaji. Jurnal Ilmiah Pertanian (JIPERTA), 2 (1): 23-32

*E-mail: meidaya19@gmail.com $\quad$ ISSN 2550-1305 (Online)

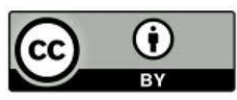


Maydaya Bate'e, Ellen Lumisar Panggabean \& Siti Mardiana, Respon Pertumbuhan Dan Produksi Beberapa Varietas Jamur Tiram Pada Kombinasi Media Serbuk Limbah Pelepah Kelapa Sawit Dan Serbuk Gergaji.

\section{PENDAHULUAN}

Produksi jamur tiram, antara tahun 2009-2013 yaitu, pada tahun 2009 produksi mencapai 61,376 ton, dan terjadi penurunan produksi pada tahun 2010 yaitu, 56,094 ton, dan sangat meningkat pada tahun 2013 yaitu 107,617 ton (Sucipto, 2014 dalam Ahmad Fauzi, 2017). Berdasarkan data Badan Pusat Statistik (BPS) (2016). produksi jamur di Sumatera Utara pada tahun 2014 mencapai 15,9 ton pada tahun 2015 16,3 ton dan pada tahun 2016 yaitu 18,5 ton, hal ini menunjukkan bahwa permintaan pasar akan jamur setiap tahunnya meningkat. Menurut Mufarrihah (2009), media tumbuh merupakan salah satu aspek penting yang menentukan tingkat keberhasilan budidaya jamur.

Media yang umum dipakai untuk membiakkan jamur tiram adalah serbuk gergaji kayu (Utami, 2017). Menurut Cahyana, dkk, (2005) keberhasilan budidaya jamur ditentukan oleh kualitas media tanam. Serbuk gergaji kayu adalah limbah dari sisa penggergajian yang biasanya dijadikan sebagai media pertumbuhan jamur tiram, Serbuk gergaji yang baik digunakan sebagai media tanam jamur tiram dari jenis kayu yang keras, dimana mengandung selulosa tinggi yang diperlukan oleh jamur tiram dalam jumlah yang banyak. ketersediaan serbuk gergaji kayu merupakan masalah bagi petani jamur yang ingin mengusahakan jamur tiram, tetapi didaerah tempat tinggalnya tidak ada atau sedikit ditemukan tempat penghasil serbuk kayu (Sidik Siregar dkk., 2019 ; Nurhijjah dkk., 2019 ; Festaria dkk., 2019). Maka dari itu perlu dilakukan kajian tentang bahan yang bisa menggantikan serbuk kayu sebagai bahan utama media buatan untuk budidaya jamur tiram. Bahan yang digunakan sebaiknya memiliki kriteria dan karakteristik yang hampir sama dengan serbuk kayu dan memiliki kandungan nutrisi yang cukup untuk mendukung pertumbuhan jamur tiram (Nasution, 2016; Nasution dkk, 2017). Oleh karena itu, untuk mengantisipasi perlu dicari alternatif media pertumbuhan yang banyak tersedia dan mudah diperoleh di daerah tersebut diantaranya limbah perkebunan kelapa sawit.

Perkebunan kelapa sawit terbesar didunia terdapat di Indonesia. Menurut Badan Pusat Statistik (BPS) Nasional luas area perkebunan kelapa sawit di sumatera utara yaitu: di tahun 2012: 1.222.91 ha, tahun 2013: 1.340.45 ha, 2014: 1.396.30 ha, 2015: 1.427.00 ha, dan pada tahun 2016: 1.342 .60 ha. Dari luas lahan perkebunan kelapa sawit yang ada di Sumatera utara menghasilkan limbah perkebunan yang cukup tinggi, mulai dari limbah cair sampai pada limbah padat seperti pelepah daun kelapa sawit (Insandi dkk., 2019 ; Harahap dkk., 2019). Menurut Natasha (2012) dalam Fauzi (2017), biomasa pelepah kelapa sawit per ha per tahunnya mencapai 6,3 ton. Menurut Goh et al, (2010) dalam Fauzi (2017), pelepah kelapa sawit mempunyai komposisi 14,8\% lignin, 62,3\% Cellulose, 24,2\% Hemicellulose. Dengan adanya limbah pelepah kelapa sawit yang tinggi dan kandungan yang terdapat di dalamnya maka limbah pelepah kelapa sawit dapat dijadikan media alternatife pertumbuhan jamur tiram. Hal ini sejalan dengan penelitian Fauzi (2017), yang memperoleh hasil bahwa penggunaan limbah pelepah sawit sebagai media pertumbuhan jamur tiram putih berpengaruh terhadap bobot panen jamur tiram putih. Hasil penelitian Mardiana, dkk., (2016), menunjukan bahwa pertumbuhan pada 
pembentukan miselium dari limbah pelepah kelapa sawit menunjukan pertumbuhan yang baik antara 35-46 hari, dibandingkan dengan limbah yang lainnya seperti blotong tebu, ampas teh, batang jagung dan batang padi. Berdasarkan uraian tersebut peneliti mengadakan penelitian tentang respon pertumbuhan dan produksi beberapa varietas jamur tiram pada media serbuk limbah pelepah kelapa sawit.

\section{METODE PENELITIAN}

\section{Persiapan Kultur Jamur Tiram}

Kultur jamur tiram putih, berasal dari sumatera kebun sedangkan jamur tiram merah, dan jamur tiram coklat. Jamur bibit yang dibutuhkan dalam proses penelitian sebanyak 6 botol ( 2 botol bibit jamur tiram putih, 2 botol bibit jamur tiram merah, dan 2 botol bibit jamur tiram coklat).

Serbuk limbah pelepah kelapa sawit yang dijadikan sebagai media dalam penelitian ini sebelumnya diperoleh dari perkebunan sawit yang selanjutnya digiling dan dihaluskan dengan menggunakan mesin penggiling sehingga menjadi serbuk dari limbah pelepah kelapa sawit. Serbuk limbah pelepah kelapa sawit yang dijemur kemudian diayak. Media tanam yang digunakan sebagai media tumbuh jamur tiram adalah kombinasi (mencampur bahan media) dengan bekatul, kapur, molase dan ampas tahu sebagai nutrisi umum serta serbuk gergaji, serbuk pelepah kelapa sawit sesuai dengan perbandingan perlakuan penelitian (Walida dkk., 2019 ; Ajiputra dkk., 2019). Perlakuan semuanya berdasarkan komposisi pembuatan media tumbuh jamur tiram putih berdasarkan penelitian yang dilakukan Fauzi (2017). Limbah pelepah kelapa sawit akan di subtitusi dengan sebuk gergaji pada varietas jamur yang berbeda Menurut Steviani (2011).

Adapun perlakuan dan factor dalam penelitian ini adalah:

\section{Faktor I}

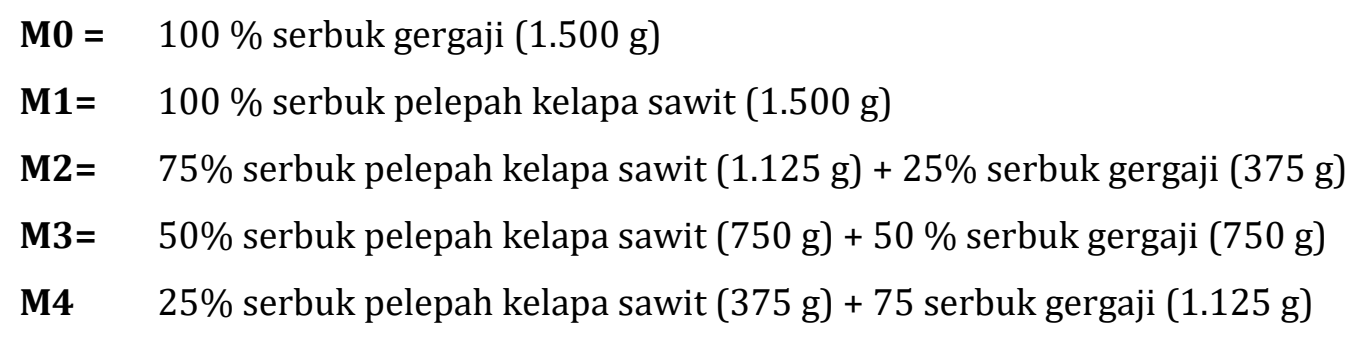

\section{Faktor II}

V1= Jamur Tiram Putih

$\mathbf{V 2}=\quad$ Jamur Tiram Merah

V3= Jamur Tiram Coklat

\section{Pengisian Media Kedalam Plastik Polipropilen (PP), Strerilisasi dan Inokulasi}

Media yang telah tercampur dan telah diberi air dengan kebasahan $60 \%$ dimasukkan kedalam plastik polipropilen berukuran $2 \mathrm{~kg}$ (sebanyak \pm 1500 gram per 
Maydaya Bate'e, Ellen Lumisar Panggabean \& Siti Mardiana, Respon Pertumbuhan Dan Produksi Beberapa Varietas Jamur Tiram Pada Kombinasi Media Serbuk Limbah Pelepah Kelapa Sawit Dan Serbuk Gergaji.

plastik dengan ketinggian media $20 \mathrm{~cm}$ ) dan dipres agar media menjadi padat. Selanjutnya, pada bagian atas plastik (leher kantong plastik) dipasang ring atau cincin pipa paralon dan dipasang penutup baglog yang terbuat dari plastik steril agar air tidak masuk ke dalam kantong plastik pada saat pengukusan, Kemudian baglog disterilkan selama 8 jam pada suhu $100^{\circ} \mathrm{C}$ dengan menggunakan drum (steril bak).

Inokulasi merupakan proses penanaman bibit ke dalam media baglog. Proses ini dilakukan dengan cara memindahkan bibit kedalam baglog hingga bagian atas baglog tertutup oleh bibit yang ditanamkan dengan alat-alat yang telah disterilkan terlebih dahulu agar tidak terjadi kontaminasi. Media yang telah diinokulasi disimpan dikumbung (tempat yang cocok untuk pertumbuhan miselium) agar miselium jamur dapat tumbuh. Inkubasi dilakukan di ruang yang sedikit gelap agar miselium lebih cepat merambat. Media akan tampak putih merata antara 30-40 hari setelah dilakukan inokulasi mengikuti prosedur yang dideskripsikan Abidin, 2017). Panen dilakukan setiap hari sesuai dengan kriteria panen (Rahmadani, 2016 dalam Abidin, 2017).

\section{Parameter Pengamatan dan Analisis Data}

Data yang menjadi parameter uji dari penelitian ini Persentase Baglog Yang Ditutupi Miselium (\%), Pertumbuhan Miselium Pada Substrat/baglog (cm), Umur Munculnya Tubuh Buah (HSI), Jumlah Tubuh Buah (Buah), Panjang Tangkai Tubuh Buah (cm), Bobot Basah Panen (g). kemudian data tersebut dianalisis dengan menggunakan perhitungan statistik mengikuti kaidah analisis RAK Faktorial.

\section{HASIL DAN PEMBAHASAN \\ Persentase Baglog Yang Ditutupi Miselium (\%)}

Baglog yang di budidayakan dengan perlakuan masing-masing mampu tumbuh 94,12\% dan beberapa baglog yang tidak tumbuh. Hal ini diduga bahwa baglog yang tumbuh di dukung oleh beberapa faktor lingkungan seperti suhu. Menurut Handrianto (2015) miselium jamur tiram akan tumbuh optimal pada suhu $25^{\circ} \mathrm{C}$ dan kelembaban udara pada 80-95\%. Selain itu miselium yang tidak tumbuh sebanyak 5.8\% disebabkan oleh adanya kontaminasi oleh jamur lain dan viabilitas dari kultur jamur tiram. Sesuai pandapat Daqua (2016) menyatakan faktor lain yang penting selama proses pertumbuhan miselium pada media tanam adalah viabilitas (daya hidup) kultur jamur serta kehadiran kontaminan.

\section{Pertumbuhan Miselium Pada Substrat/baglog (cm)}

Pertumbuhan Miselium beberapa varietas jamur tiram diperlihatkan pada grafik pada Gambar 1. 

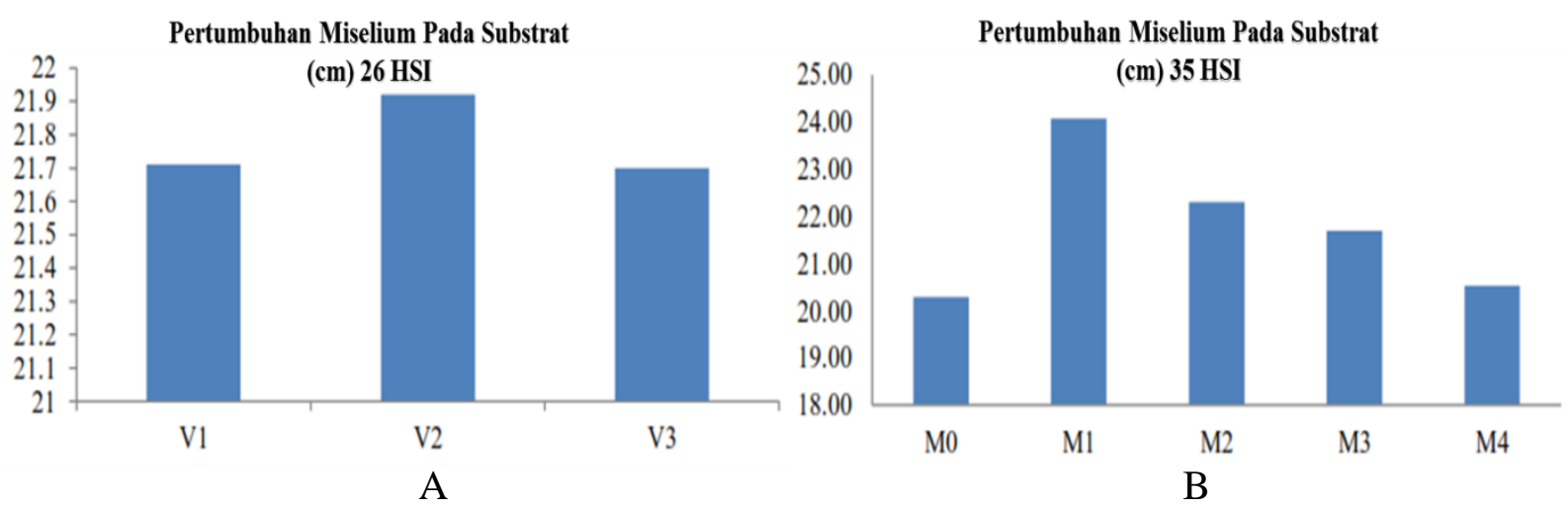

Gambar 1. Pertumbuhan miselium pada substrat

Gambar 1 menunjukkan bahwa perlakuan V (varietas jamur tiram) berpengaruh sangat nyata pada umur 8, 11 dan 26 HSI dengan perlakuan terbaik adalah V2 pada umur 35 HSI (jamur tiram merah). Hasil penelitian diduga bahwa jamur tiram merah memiliki umur panen yang lebih cepat sehingga pertumbuhan miselium sangat cepat memenuhi baglog. menurut Fadillah (2010), Pertumbuhan miselium jamur tiram merah berlangsung lebih kurang 1 bulan hingga memenuhi seluruh baglog. Hasil penelitian diduga media tempat tumbuhnya miselium belum terdekomposisi dengan sempurna sehingga hara yang disumbangkan oleh media masih sedikit.

Perlakuan media terbaik pada gambar 16 (data terakhir) yaitu M1 (100\% serbuk limbah pelepah sawit) hal ini diduga bahwa serbuk limbah pelepah kelapa sawit memiliki partikel yang lebih besar dibanding dengan serbuk gergaji sehingga menyediakan faktor tumbuh yang dibutuhkan jamur tiram seperti oksigen yang cukup. Menurut Frendi (2010), oksigen merupakan salah satu faktor penting yang dibutuhkan untuk pertumbuhan miselium dan pembentukan tubuh buah jamur, jika kekurangan oksigen maka tangkai tubuh buah jamur akan tumbuh memanjang dan tudungnya menjadi kurang berkembang. Selain itu diduga pelepah sawit mampu menyumbangkan nutrisi yang dibutuhkan jamur. Menurut Kartolo (2014) serbuk pelepah kelapa sawit memiliki potensi menyumbangkan hara dari kandungan lignin dan selulosa yang ada.

\section{Umur Muncul dan Jumlah Tubuh Buah}

Data umur muncul tubuh buah dirangkum kedalam grafik pada Gambar 2. 
Maydaya Bate'e, Ellen Lumisar Panggabean \& Siti Mardiana, Respon Pertumbuhan Dan Produksi Beberapa Varietas Jamur Tiram Pada Kombinasi Media Serbuk Limbah Pelepah Kelapa Sawit Dan Serbuk Gergaji.

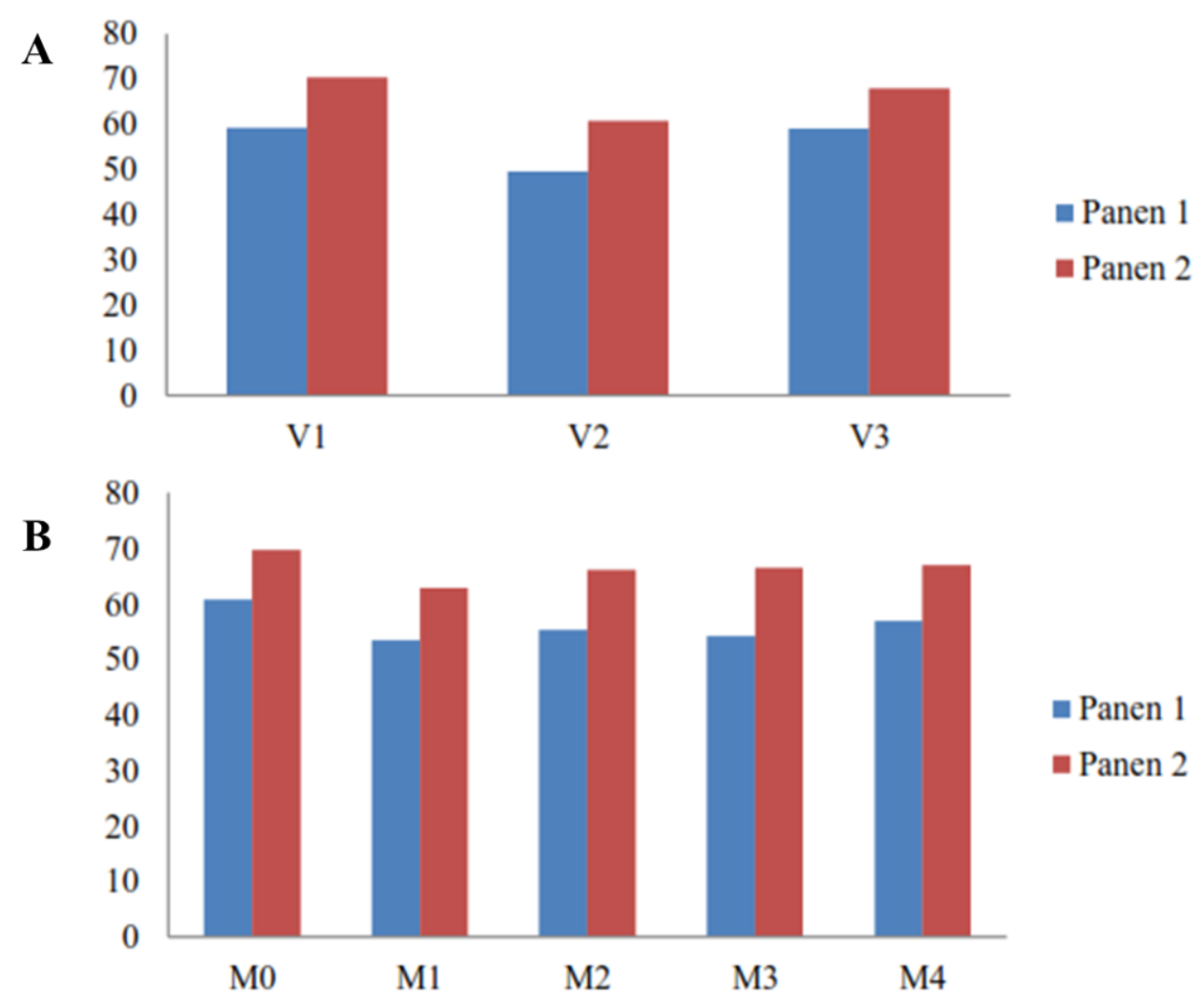

Gambar 2. Pertumbuhan miselium pada substrat, A. Pada 26 HSI, B Pada 35 HSI

Hasil penelitian ini diduga bahwa kandungan yang terdapat pada media M1 sudah terdekomposisi dengan sempurna serta karena adanya penambahan bekatul, molase dan ampas tahu sebagai nutrisi. Sebagaimana kandungan serbuk pelepah sawit menurut Kartolo, (2014) menunjukkan bahwa pelepah sawit memiliki 14,8\% lignin, 62,3\% selulosa dan 24,2\% hemiselulosa, dimana kandungan ini dapat diubah menjadi nutrisi yang dibutuhkanjamur tiram. Wulan et al., (2007), menyatakan bahwa penambahan bekatul akan mempercepat waktu munculnya tubuh buah. Interaksi perlakuan $\mathrm{V}$ dan $\mathrm{M}$ menunjukkan berpengaruh tidak nyata pada umur mucul tubuh buah pertama dan kedua. Namun jika dilihat rataan perlakuan, perlakuan M1V2 (limbah serbuk pelepah sawit dan jamur tiram pink) adalah perlakuan terbaik pada muncul tubuh buah pertama maupun kedua yaitu 46.75. Menurut Humas Balitsa (2018) pada lampiran 3, bahwa waktu awal panen jamur tiram yaitu berkisar 38-74 hari setelah inokulasi, yang berarti tidak menunjukkan hasil yang berpengaruh nyata.

Data lain adalah rataan jumlah tubuh buah yang dirangkup pada table 1. 
Tabel 2. Rataan Jumlah Tubuh Buah Pada Beberapa Varietas Jamur Tiram Akibat Pemberian Komposisi Media Limbah Serbuk Pelepah Kelapa Sawit dan Serbuk Serbuk Gergaji (buah)

\begin{tabular}{ccc}
\hline \multirow{2}{*}{ Perlakuan } & \multicolumn{2}{c}{ Jumlah Tubuh Buah } \\
\cline { 2 - 3 } & Panen I & Panen II \\
\hline Varietas & $14.23 \mathrm{a} \mathrm{A}$ & $22.32 \mathrm{a} \mathrm{A}$ \\
V1 & $13.85 \mathrm{a} \mathrm{A}$ & $18.65 \mathrm{~b} \mathrm{~B}$ \\
V2 & $8.65 \mathrm{~b} \mathrm{~B}$ & $8.03 \mathrm{c} \mathrm{C}$ \\
\hline Media & & \\
\hline M0 & $10.92 \mathrm{bc} \mathrm{AB}$ & $14.33 \mathrm{bc}$ \\
M1 & $12.79 \mathrm{ab} \mathrm{AB}$ & $14.42 \mathrm{ab}$ \\
M2 & $14.5 \mathrm{a} \mathrm{A}$ & $18.21 \mathrm{a}$ \\
M3 & $13.25 \mathrm{ab} \mathrm{AB}$ & $17.45 \mathrm{ab}$ \\
M4 & $9.75 \mathrm{c} \mathrm{B}$ & $17.25 \mathrm{c}$ \\
\hline Interaksi & & $19.88 \mathrm{tn}$ \\
M0V1 & $10.75 \mathrm{tn}$ & $16.38 \mathrm{tn}$ \\
M0V2 & $15.25 \mathrm{tn}$ & $6.75 \mathrm{tn}$ \\
M0V3 & $6.75 \mathrm{tn}$ & $20.50 \mathrm{tn}$ \\
M1V1 & $14.63 \mathrm{tn}$ & $14.75 \mathrm{tn}$ \\
M1V2 & $13.00 \mathrm{tn}$ & $8.00 \mathrm{tn}$ \\
M1V3 & $10.75 \mathrm{tn}$ & $24.00 \mathrm{tn}$ \\
M2V1 & $17.63 \mathrm{tn}$ & $23.38 \mathrm{tn}$ \\
M2V2 & $16.75 \mathrm{tn}$ & $7.25 \mathrm{tn}$ \\
M2V3 & $9.13 \mathrm{tn}$ & $24.35 \mathrm{tn}$ \\
M3V1 & $16.38 \mathrm{tn}$ & $19.13 \mathrm{tn}$ \\
M3V2 & $13.13 \mathrm{tn}$ & $8.88 \mathrm{tn}$ \\
M3V3 & $10.25 \mathrm{tn}$ & $22.88 \mathrm{tn}$ \\
M4V1 & $11.75 \mathrm{tn}$ & $19.63 \mathrm{tn}$ \\
M4V2 & $11.13 \mathrm{tn}$ & $9.25 \mathrm{tn}$ \\
M4V3 & $6.38 \mathrm{tn}$ & $5 \mathrm{berb}$ \\
\hline
\end{tabular}

Keterangan : Angka yang diikuti huruf yang sama menunjukkan berbeda tidak nyata pada taraf .05 (huruf kecil) dan .01 (huruf besar)

Tabel 1 Menunjukkan bahwa jumlah tubuh buah terbanyak yaitu V1 (jamur tiram putih) baik pada panen pertama maupun pada panen kedua dan tidak berbeda nyata dengan V2 (jamur tiram merah) pada panen 1 serta berbeda sangat nyata dengan perlakuan lainya pada panen kedua. Hal ini diduga bahwa pada saat pengamatan, miselium varietas V1 lebih padat dan tebal jika dibandingkan dengan varietas lainya dimana miselium varietas V1 pada semua media yang berbeda menunjukkan miselium yang tebal dan terlihat padat pada media baglog, hal ini sesuai dengan pendapat Hapsari (2014), yang menyatakan pada proses pembentukan tubuh buah sangat dipengaruhi oleh pertumbuhan miselium semakin baik miselium yang tubuh maka akan menghasilkan tubuh buah yang baik. 
Maydaya Bate'e, Ellen Lumisar Panggabean \& Siti Mardiana, Respon Pertumbuhan Dan Produksi Beberapa Varietas Jamur Tiram Pada Kombinasi Media Serbuk Limbah Pelepah Kelapa Sawit Dan Serbuk Gergaji.

Berdasarkan data menunjukkan bahwa perlakuan terbaik yaitu V3 (jamur tiram cokelat) yang berbeda nyata dengan V1 (Varietas jamur tiram putih) serta sangat nyata berbeda dengan V2 (varietas jamur tiram merah) pada panen ke-2. Hasil penelitian diduga bahwa setiap varietas jamur tiram memiliki karakteristik diameter tubuh buah masing-masing yang berbeda. Menurut Critine (2017), menyatakan bahwa jamur tiram cokelat memiliki diameter 5-12 cm dan lebih besar dibandingkan dengan varitas jamur tiram merah dan coklat.

\section{SIMPULAN}

Penggunaan beberapa varietas jamur tiram berpengaruh sangat nyata pada semua parameter pengamatan, dengan varietas V1 terbaik yang berbeda nyata dengan varietas V2 dan V3 pada jumlah tubuh buah dan bobot basah panen. Perlakuan penggunaan media limbah serbuk pelepah sawit berpengaruh sangat nyata pada parameter pengamatan pertumbuhan miselium, umur munculnya tubuh buah dan jumlah tubuh buah, dengan perlakuan terbaik pada umur 35 HSI yaitu M1 yang berbeda nyata dengan media lainya. serta berpengaruh tidak nyata terhadap diameter tudung buah, panjang tangkai dan bobot basah panen. Interaksi beberapa varietas dan kombinasi media serbuk pelepah kelapa sawit dan serbuk gergaji menunjukkan pengaruh nyata pada parameter panjang tangkai, dengan perlakuan terbaik M2V3 yang tidak berbeda nyata dengan perlakuan M0V3, M3V3, dan M4V1 dan berbeda nyata dengan perlakuan lainya, serta berpengaruh tidak nyata terhadap parameter lainya.

\section{UCAPAN TERIMAKASIH}

Studi ini diselesaikan dengan bimbingan yang Dr. ir. Siti Mardian dan Ir. Ellen Lumisal Panggabean dan atas dukungan rekan mahasiswa di program studi Agroteknologi.

\section{DAFTAR PUSTAKA}

Abidin A. (2017). Formulasi Media Blotong Tebu, Serbuk Gergaji dan Kapur Sebagai Media Pertumbuhan dan Produksi Jamur Tiram Putih (Pleurotus ostreatus).

Ajiputra, R., Hasnudi, H., \& Pane, E. (2019). Analisis Strategi Pengembangan Sapi Pakan Alternatif dari Pelepah Kelapa Sawit di Kabupaten Asahan. AGRISAINS: Jurnal Ilmiah Magister Agribisnis, 1(1), 8999.

Anitasari, E., Prihastanti, E., \& Arianto, F. (2019). PENGARUH RADIASI PLASMA DAN PUPUK KANDANG KAMBING TERHADAP PERTUMBUHAN BAWANG MERAH VARIETAS BIMA BREBES. BIOLINK : Jurnal Biologi Lingkungan Industri Kesehatan, 6(2), 114-125. doi:https://doi.org/10.31289/biolink.v6i2.2639

Fadillah N. (2010). Tips Budidaya Jamur Tiram. Yogyakarta: Genius Publisher.

Fauzi A. (2017). Pengaruh pemberian nutrisi pada komposisi media serbuk pelepah kelapa sawit dan gergaji Terhadap pertumbuhan dan produksi Jamur tiram putih (Pleurotus ostreatus).

Festaria, L., Ginting, R., \& Siregar, M. (2019). Analisis Produksi Jagung dengan Penyertaan Dana Penguatan Modal Lembaga Usaha Ekonomi Pedesaan (Dpm-Luep) di Provinsi Sumatera Utara. AGRISAINS: Jurnal Ilmiah Magister Agribisnis, 1(2), 138-145.

Frendi R. (2010). Pembibitan Jamur Tiram (Pleurotus ostreatus) di balai Pengembangan dan Promosi Tanaman Pangan dan Hortikultura (BPPTPH) Ngipiksari Sleman, Yogyakarta. In: Tugas Akhir: UNS.

Hapsari WE. (2014). Pertumbuhan dan Produktifitas Jamur Tiram Putih (Pleurotus Ostreatus) Pada Media Serbuk Gergaji Kayu Jati (Tectona Grandis L) dengan Penambahan Sekam Padi (Oryza Sativa). Universitas Muhammadiyah Surakarta, 
Harahap, S., Lubis, Z., \& Rahman, A. (2019). Analisis Potensi dan Strategi Pemanfaatan Limbah Kelapa Sawit di Kabupaten Labuhanbatu. AGRISAINS: Jurnal Ilmiah Magister Agribisnis, 1(2), 162-176.

Insandi, A., Kuswardhani, R., \& Sibuea, M. (2019). Analisis Studi Kelayakan Bisnis Pemanfaatan Limbah Agribisnis Menjadi Energi Alternatif di Kecamatan Tanah Jawa Kabupaten Simalungun. AGRISAINS: Jurnal Ilmiah Magister Agribisnis, 1(1), 18-30.

Irhananto Y. (2014). Pertumbuhan Dan Produktifitas Jamur Tiram Putih (Pleurotus Ostreatus) Pada Komposisi Media Tanam Ampas Kopi Dan Daun Pisang Kering Yang Berbeda. Universitas Muhammadiyah Surakarta,

Kartolo R. (2015). Penggunaan Pelepah Kelapa Sawit Yang Difermentasi Dengan Mikroba Lokal Pada Domba Lokal Jantan.

Mugiono S, Tias Arlianti S, \& Chotimatul Azmi S. (2011). Panduan Lengkap Jamur: Penebar Swadaya Grup.

Nasution, J. (2016). Kandungan Karbohidrat dan Protein Jamur Tiram Putih (Pleurotus Ostreatus) Pada Media Tanam Serbuk Kayu Kemiri (Aleurites Moluccana) dan Serbuk Kayu Campuran. EKSAKTA: Jurnal Penelitian Dan Pembelajaran MIPA, 1(1).

Nasution, J., Handayani, H., \& Riyanto, R. (2017). PENGARUH OLAHAN BERBAGAI PRODUK MAKANANTERHADAP KADAR PROTEIN PADA JAMUR TIRAM PUTIH (Pleurotus ostreatus). Eksakta: Jurnal Penelitian Dan Pembelajaran MIPA, 1(2).

Nurhijjah, N., Kuswardhani, R., \& Kardhinata, E. (2019). Dampak Serangan Organisme Pengganggu Tanaman dan Perubahan Iklim terhadap Produksi dan Pendapatan Petani Padi Sawah di Sumatera Utara. AGRISAINS: Jurnal Ilmiah Magister Agribisnis, 1(1), 79-88.

Sidik Siregar, R., Pane, E., \& Mardiana, S. (2019). Pengujian Beberapa Varietas Jamur Tiram Pada Kombinasi Mediaserbuk Ampas Tebu Dan Serbuk Gergajian Dengan Penambahan Molase Dan Limbah Ampas Tahu.. Jurnal Ilmiah Pertanian ( JIPERTA), 1(1), 26-36.

Siti M. (2016). Pengolahanlimbah Pertanian dan Perkebunan Sebagai Media Pertumbuhan Jamur Tiram (Pleurotus Ostreatus).

Steviani S. (2011). Pengaruh penambahan molase dalam berbagai media pada jamur tiram putih (Pleurotus ostreatus).

Utami CP. Pengaruh Penambahan Jerami Padi Pada Media Tanam Terhadap Produktivitas Jamur Tiram Putih (Pleurotus Ostreatus).

Walida, H., Harahap, F., Hasibuan, M., \& Yanti, F. (2019). ISOLASI DAN IDENTIFIKASI BAKTERI PENGHASIL IAA DAN PELARUT FOSFAT DARI RHIZOSFER TANAMAN KELAPA SAWIT. BIOLINK : Jurnal Biologi Lingkungan Industri Kesehatan, 6(1), 1 - 7. doi:https://doi.org/10.31289/biolink.v6i1.2090

Wulan C, Sri T, \& Arif W. (2007). Pengaruh penambahan bekatul dan eceng gondok pada media tanam terhadap hasil dan kandungan protein jamur tiram (Pleurotus ostreatus). Jurnal Pertanian, 1(1).

YA C, \& Muchordji MB. (2001). Pembibitan, Pembudidayaan, analisa Usaha Jamur Tiram. Penebar Swadaya. Jakarta. 